\title{
Goal Setting for Students Participating in Student Exchange Programs Between Universities in Indonesia
}

\author{
Aniq Hudiyah Bil Haq ${ }^{1 *}$ Gema Lara Fahmi ${ }^{1}$ Puspa Ghandi ${ }^{1}$ Khusnul Khatimah ${ }^{2}$ \\ Dewi Puri Astiti ${ }^{3}$ Jusuf Blegur ${ }^{4}$ \\ ${ }^{l}$ Faculty of Psychology, Universitas Muhammadiyah Kalimantan Timur \\ ${ }^{2}$ Faculty oof Teacher Training and Education, Universitas Muhammadiyah Kalimantan Timur \\ ${ }^{3}$ Department of Psychology, Faculty of Medical, Universitas Udayana \\ ${ }^{4}$ Department of Physical Education Health and Recreation, Universitas Kristen Artha \\ Wacana \\ "Corresponding author. Email: *ahbh186@umkt.ac.id
}

\begin{abstract}
Proper and precise goal setting will encourage an individual to achieve objectives. Besides, the current online lecture model directs students to have good self-regulation so that the learning process can be maintained optimally and results in the expected performance. Goal setting stimulates students to use learning strategies independently and also manage learning activities to increase academic success. This study explores forms of goal setting for online lectures and, more specifically, for students who take lecture credits outside their home universities but still in the Indonesian university. The data collected from in-depth interviews, direct observation, and documentation studies remain to be confirmed to produce accountable strategic model data according to the subject's experience. Interview guidelines were used to obtain forms and dynamics in setting goals of the students, who are taking courses in their university. The subjects involved in this study consisted of 14 students who took several online lectures that were named student exchange program. The results obtained in this study show that preparation for student exchange participation is required so that the goal setting for participating in this program can be maintained adequately. The learning process during the student exchange process should be monitored from the beginning by the student's academic supervisor at the home university. The function of the academic supervisor is as a mentor for students to take lectures outside their universities.
\end{abstract}

Keywords: goal setting, student exchange, online lecture

\section{BACKGROUND}

Transformation in the education milieu always follows time changes because education is the foundation for adapting to his ever-dynamic environment. Educational institutions as a place to gain knowledge are expected to equip students to become a sophisticated generation who is creative and innovative so that it is possible to build a better Indonesia.

The Freedom to Learn Free Campus policy that the Minister of Education and Culture launched is expected to prepare students to become resilient scholars according to their competencies and time and become leaders with a high national spirit. The paradigm adopted in this program emphasizes that learning can be conducted without being limited to the classroom so that students can study anywhere, anytime, and with anyone to their interests. This program also highlights that learning is not only in the library or laboratories but also in the real world involving the industrial and rural settings. Based on Regulation of Minister of Education and Culture Number 3 of 2020 Article 15 paragraph 1, learning activities can be carried out within or outside study 
programs, including student exchange, internships, or teaching assistantship in research education unit or research projects, humanitarian activities, entrepreneurial studies or independent projects, and thematic student study service (kampusmerdeka.kemdikbud.go.id/).

Respecting choices and allowing students freedom of learning are the keywords in the Freedom to Learn as a form of optimizing students' abilities to learn driven by desire without any force and according to their interests so that learning motivation emerges. Interest in one particular subject can affect student learning outcomes in that course, and it is imperative to foster interest in learning [1], [2]. With the Freedom to Learn, students are facilitated to study based on their passion. They must be counterbalanced with goal setting and good self-regulation to affect their academic performance [3], [4]. Good academic performance may result in successful lectures such as maximum grades, a good understanding of the material, and learning experiences that can be applied in real life. One of the academic performances is assignments given by lecturers.

Setting goals for each individual has different dynamics, given each individual's perspective on interpreting failure and success [5], [6]. Goal setting can be influenced by past experiences, whether it is experienced by oneself or by others.

The purpose of this study is to investigate students' dynamics in shaping goal setting in online lectures, especially when they participate in a student exchange program or take a course at other universities than their home universities. Data collection in this study is a qualitative exploration to explore the meaning of strategies for students in improving academic performance while enrolling in courses at different universities through goal setting. The results obtained in this study can be a strategy to prepare students for in Freedom to Learn program, which will be applied in Indonesian universities.

Goal setting is closely related to the environmental function that controls the establishment of goals following individual and social expectations. In students, goal setting is influenced by lecturers, parents, peers, and even economic factors, yet adequate goal setting is based on an individual's circumstances. The clearer a person describes goal setting, the easier the strategy that leads to his goal. Therefore, goal setting is also shaped by cognitive factors and the individual [7], [8]. It can be considered that goal setting is an ongoing process and not only done at the beginning by expressing the expectation. It is proven by a clear commitment, focusing on the process and not on the results, so an individual who can describe his goals thoroughly will lead his actions to those goals. The success to establish a goal in a particular field will eventually ease the goal setting in another field, meaning that an individual who succeeds in achieving his goal in one field will lead him to succeed in another one.

Setting reasonable goals will facilitate someone to measure their achievement because they already have their standards of success at the beginning. In this study, it was found that the lecturer's factor in describing the form of a clear assessment would help students to understand their position. A person who has good goal setting will produce a good impact as well.

Student learning performance can increase because they can set goals [9]. Goal setting may stimulate students to use self-directed learning strategies and management techniques in activities that enhance their academic success [10]. Goal setting can be expressed as a strategy that students often use to transform their learning activities, commit to their learning goals and improve their academic performances [11]-[13]

In learning activities, students may have good academic performance and otherwise. This is undoubtedly motivated by various variables, both internal and external factors. Not all students with good academic performance are well-balanced and consistent. Nonetheless, they have several strategies for overcoming their learning difficulties. The impact of good goal setting is the presence of good selfregulation, so the effect can be directly experienced through behaviors that lead to goal achievement. Student performance on assignment completion by lecturers is exhibited from behavior that responds efficiently to assignments, avoids delaying assignment submission, and is assertive to lecturers and friends to compile assignments according to the lecturer's expectation [14]. Thus, good academic performance through performance on each assignment is not instant, but a "perfection" of students' long exploration process.

A study of the steps to the success goal setting, for instance, according to the explanation of [15] offers four practical steps, comprising: 1) Goal setting must be specific, measurable, realistic, clear, and achievable. 2) There is an action plan that will be gone through 3) Progress is adequately monitored regularly 4) Appreciate every achievement regardless of the scale.

The success of students in improving academic performance needs to be further explored, so it becomes a new model of goal setting strategy for those who have not been able to maintain and improve academic performance through assignments in the course while following the learning process, thus 
learning class becomes competitive, productive, and collaborative, and completed.

Students who have goal setting more focus compared to those without goal setting. Their focus is aimed at the goals that have been predetermined as what they desired once learning activities are completed. To tally with the understanding of goal setting, [16] define goal setting as the process of setting clear goals and is used for learning activities. Goal setting assists students to focus on the environment they have planned so they make efforts to achieve it. Shortly, goal setting helps students change from time to time, from low to a high level.

Goal setting is the motivation for students to achieve maximum results and the perception that "only to submit assignments" will change because the quality and totality of the assignments become assessment form and specific form of goal setting, making students assess their performance. Students will always follow and reflect on themselves with a set of skills on the goals they have determined. It is interpreted as a process of assessing performance, in which students evaluate their performance to support predetermined goal setting. This series of processes implies that goal setting provides critical selfevaluation and assessing that effort is mandatory. Another impact of self-assessment can be observed when students obtain bad grades, they will not protest against their lecturers but will ask themselves for the work they have done.

The concept of goal setting has become an essential part of the education setting to improve student academic performance [7]. Students do not attend class to "follow" all the lecturer's orders, but they need to align their innate goals. There must be a reason they want to attend a class and what they will achieve after learning certain materials or passing specific courses. Several cases show that learning outcomes are complex for students to succeed because they are not encouraged to be actively involved. There is nothing that excites them to learn because there is no stimulation of a robust vision. As a result, the learning activities students are engaged in only cover administration (attendance). For example, students in a class have been mediated with presentation guidelines that will be used to diagnose their omissions. Unfortunately, these omissions are not followed up with improvements. Therefore, changes in learning (such as presentation skills in the classroom) have not changed significantly.

Students with learning goal orientation tend to choose assignments in which they can acquire knowledge and skills [17]. They seek information about how to achieve goals and what skills are required to expedite the process of achieving them.
[12] expressed that when individuals are used to evaluating performance related to feedback on results, they have created commitment. Learning goal orientation leads to higher performance by making improvements as a manifestation of commitment and goal setting. In addition, other supporting aspects are ability, self-efficacy, revision due date, and the effectiveness of the goals set.

Goal setting can provide attractiveness and active power to students in learning because it contributes to direct energy, ultimately affecting certain learning behaviors. It signifies that students will be more enthusiastic, develop strategies for the next semester, and increase persistent efforts to achieve the expected results or behavior [7]. Goal setting expressed directly and clearly can give a person good emotions, thus achieving goals becomes easier [18] and accelerates learning achievement [16]. Furthermore, goal setting is also a strategy to improve academic performance [19]. Goal setting also encourages student learning motivation because learning goals are more visible and apparent [7]. For this reason, educators must be able to facilitate practical goal-setting interventions in the learning process, both individually and collectively [16], [20]. Based on the explanation of previous studies, it can be determined that goal setting and selfregulation are essential in creating good academic performance. Previous studies have not highlighted the goal setting made by students with online lectures and attending lecture programs outside the home university. Therefore, this study will explore goal setting strategy to carry out the lecture process well.

\section{METHOD}

This study used an explorative study in qualitative approach to identify the psychological picture of the subject regarding the purpose of participating in the student exchange program. The subjects involved in this study comprised 14 students taking online lectures of one course in the student exchange program in Indonesia, the destination university is one of the state universities in Bali. Sampling was carried out using the purposive sampling technique. The subject criteria consist of students participating in the student exchange program at a university outside of their home university.

Data were collected from questionnaires with open-ended questions, FGD, interviews, and documentation of learning outcomes. The data were then confirmed to produce accountable strategic model data according to students' experience. Interview guidelines were referred to obtain forms and dynamics in goal setting for students taking a course outside their home university. 
The following are examples of open-ended questions included in the questionnaire:

a. What did you think when you first learned about the exchange student program?

b. What is your reason for joining the exchange student program?

c. What is your goal in joining this program?

d. After attending this course for approximately seven weeks, how do you feel?

e. Are there any difficulties while attending lectures at other universities? Can you explain the problem?

The interview guidelines are as follows:

a. Goal Setting:

b. Explain the initial process of joining the exchange student program?

c. The reason for joining the exchange student program at another university?

d. Describe the course of study that has been undertaken so far?

e. Are the courses taken following the field of interest?

f. Is there any encouragement from friends to join this program?

g. What difficulties did you experience while studying psychology this semester?

h. How to deal with the challenges of studying in the Psychology study program this semester?

i. Have a specific schedule or place to study?

j. Specifically for the exchange student program, do you have a different strategy?

Data analysis using categorization filtered the themes emerging from the answers of the subjects. Data analysis techniques include 1) processing and preparing data for analysis, 2) reading overall data, 3) analysis in more detail by coding the data, 4) applying the coding process, 5) showing again how these descriptions and themes will be restated in the report [21].

\section{RESULT AND DISCUSSION}

\subsection{Students' Knowledge of Exchange Program}

Based on the results of the categorization, it was found that all subjects initially did not know about the exchange program, because it was the first time this program was conducted by the Psychology faculty at their home University. The subject then received information from the management of the study program that students could take lectures in several courses at other universities. In this program, students can take one of the 7 courses offered. Information about lectures is obtained in the Force group, academic advisory group, study program website and social media owned by the study program. This Student Exchange Program is a pilot for a program that has been launched by the Indonesian government under the name Merdeka Belajar Kuliah Merdeka, later students throughout Indonesia can take courses at other universities and different study programs. Based on the rules made by the Indonesian Ministry of Culture and Culture, one of the rules is that students can have the Right to Study for three semesters outside the Study program [22], [23].

The Student Exchange Program is a program that has been carried out for a long time, there has even been a cross-country student exchange program with various objectives such as getting to know the culture of each country, finding new friends and getting experiences that no one has ever met [24]. According to previous research subjects in this research perceived that this program would be an opportunity for them to gain new knowledge by studying in different universities and getting experience differently from lecturers outside the home university.

The subject confirms that academic advisor in home university helps to provide knowledge about the advantages and disadvantages of participating in a student exchange program. The academic counselling process includes taking courses that should be tailored to the interests of each student. In addition, students must adjust to the time of lectures at the home university. Student and lecturer as an academic advisor meet to discuss the selection of courses at other universities for the consideration of students. Academic advisors assist with goal setting, degree planning, and major and career exploration [25], [26].

\subsection{Students' Purpose to Follow the Program}

Regarding the determination of the goal of the subject in this study, they set the same purpose that students looked at the courses offered at partner universities and showed interest in taking these courses because the courses were not yet available at their home university. Hence, these students discerned that these courses were fascinating to learn. Another answer from students is that they wanted to experience a different atmosphere by studying with lecturers at a partner university. Based on the FDG results, students perceived those lectures outside their university taught in a separate system from the learning process they had been experiencing so far. Besides that, the reason why follows this program is that they don't want to waste the opportunity.

To achieve good career maturity, students usually begin to consider their interests after graduating from college [27]. One of them is carrying out activities 
related to their interests. Through this student exchange program, students take advantage of the opportunity to gain new knowledge they need by taking courses that are relevant to their future career interests, especially since these courses are not available at their home university, so this is the reason why students who are the subjects of this study are interested in joining the program.

\subsection{Students' Goals}

The forms of goal setting reported by the subject are related to the addition of knowledge and experience during the student exchange program. The addition of experience means is an experience in a lecture method that is different from the previous one. There is also a sense of pride because the destination university is a reputable public university. Goals of all the subjects not specific in academic achievement but in personal experience to enrich knowledge in the field of interest by taking courses that are considered applicable at work. Besides, subject also reported building relationships with other students from various universities is a valuable experience. They expressed it with a desire to discuss with each other and work in groups on the same project.

Indicators of success in participating in student exchanges are expressed by understanding new perspectives from the material provided by the lecturers obtained during the student exchange program. The subject does not describe getting a satisfactory score as their goal in joining this program but rather emphasizes the exploration of the fields of study offered in the course. The manager of the study program at the home university and the destination university makes an introductory activity about who is the lecturers, how teaching methods and materials before students decide to take courses at outside universities. This orientation is the basis of the subject in determining his choice to follow the program and what courses he finally takes.

Based on previous studies specific goals can make it easier for someone to achieve what they want [4], [28]. Setting goals for each individual has different dynamics, given each individual's perspective on interpreting failure and success [5], [6]. Goal setting can be influenced by past experiences, whether it is experienced by oneself or by others. Goal setting expressed directly and clearly can give a person good emotions, thus achieving goals becomes easier [18] and accelerates learning achievement [16]. Goal Setting for students participating in student exchange programs from subject this research needs to be more specific to measure the learning goals such as competencies they want to achieve.
In student exchanges that are carried out between foreign universities, the student exchange process is more directed to the process of cultural adaptation and mutual elimination of prejudices that are not good between students from various countries [24]. Student exchange programs in the country even in different provinces still need adaptation proses, such as major religion at them from, communication skills dan also prior knowledge they have before.

\subsection{Lecturers Perspective in the Student Exchange Program}

Furthermore, the results of FGD with lecturers in the student exchange program obtained that they felt different treatment in the learning process, such as religious beliefs, since the home university and partner university had a different religious majority. Examples in this process can be seen when giving examples in existing cases as part of the teaching and learning process. Another significant result in data collection is the importance of the academic supervisor's role in deciding the courses taken by students. Academic supervisors were required to have students' track records in the learning process so that students could maintain their academic performance during lectures in a partner university [26].

This study focuses more on the subjective experience of the subject regarding his condition. It relates to the student exchange system that exists at a home university and partner university, so that much data was analyzed as a result of the research. In-depth interviews were hampered by the online process, affecting FGD carried out online where most subjects closed the video due to network issues since observing the expressions of the subjects was also essential to obtain research data.

As input for researchers who are interested in the same theme can explore the measurement of goal setting with a quantitative approach. Measurement begins with compiling measuring instruments related to setting goals for students who take part in student exchange programs in the country as well as the MBKM (Freedom learning program).

\section{CONCLUSION}

The results of this study showed student preparation to take part in the student exchange program. Preparation began by providing sufficient knowledge to students about the program. Students were interested in joining a student exchange program because they looked at the courses offered by the partner university. Frequently, the courses offered by the partner university of student exchange program are courses that are unique to the university. It could also be related to the demographic conditions of the area so 
that there are courses that are unavailable at the home university. The role of the academic supervisor to determine student interest, guide, monitor, and evaluate is very significant. It is necessary to have a structured system for students who take part in the student exchange program so that it can be adequately maintained. The different perception of the learning process is its uniqueness which becomes a valuable experience for students to learn about the roots of culture in various regions in Indonesia. Diversity and tolerance during the teaching and learning process in the student exchange program is the key to this program. Goal Setting for students participating in student exchange programs from subject this research needs to be more specific to measure the learning goals such as competencies they want to achieve.

\section{AUTHORS' CONTRIBUTIONS}

Ahbh searches for data regarding the things to be researched limits research studies and studies the phenomena that occur. Glf and Pg conducted data collection on the research subject. Kk and Jb searched for academic studies. Dpa prepares secondary data and data processing. All the authors do the final analysis of the discussion and conclusions

\section{ACKNOWLEDGMENTS}

Author Special Thanks to Udayana University and Muhammadiyah Kalimantan Timur University to allow collecting data from both universities.

\section{REFERENCES}

[1] J. Jeranah, S. Nur, and N. Nurmiati, "FaktorFaktor Yang Mempengaruhi Kesulitan Dan Minat Belajar Mahasiswa Jurusan Pendidikan Biologi Universitas Sulawesi Barat," Saintifik, vol. 1, no. 2, pp. 87-94, 2018, doi: 10.31605/saintifik.v1i2.87.

[2] S. Norhidayah, "Pengaruh Minat Dan Kebiasaan Belajar Terhadap Prestasi Belajar," J. Eklektika, vol. 2, no. April, pp. 60-66, 2014, [Online]. Available: http://jurnal.unma.ac.id/index.php/CP/article/ view/338.

[3] J. Gómez-Miñambres, "Motivation through goal setting," J. Econ. Psychol., 2012, [Online]. Available: https://www.sciencedirect.com/science/article /pii/S0167487012000967.

[4] H. L. Tosi, E. A. Locke, and G. P. Latham, "A Theory of Goal Setting and Task Performance," Acad. Manag. Rev., vol. 16, no.
2, p. 480, 1991, doi: 10.2307/258875.

[5] R. Kanfer, P. L. Ackerman, T. C. Murtha, and ..., "Goal setting, conditions of practice, and task performance: A resource allocation perspective.," J. Appl. ..., 1994, [Online]. Available:

https://psycnet.apa.org/record/1995-12310001.

[6] R. W. Renn and D. B. Fedor, "Development and field test of a feedback seeking, selfefficacy, and goal setting model of work performance," J. Manage., 2001, [Online]. Available:

https://journals.sagepub.com/doi/abs/10.1177 /014920630102700504.

[7] Z. Bin Abu Bakar, L. M. Yun, N. S. Keow, and T. H. Li, "Goal-Setting Learning Principles: A Lesson From Practitioner," J. Educ. Learn., vol. 8, no. 1, p. 41, 2014, doi: 10.11591/edulearn.v8i1.204

[8] O. Tutuk and A. Arsanti, "HUBUNGAN ANTARA PENETAPAN TUJUAN, SELFEFFICACY DAN KINERJA," J. Bisnis dan Ekon. (JBE), vol. 16, no. 2, pp. 97-110, 2009.

[9] E. A. Locke and G. P. Latham, "Building a practically useful theory of goal setting and task motivation: A 35-year odyssey.," Am. Psychol., 2002, [Online]. Available: https://psycnet.apa.org/doiLanding?doi=10.1 037/0003-066X.57.9.705.

[10] L. Morin and G. Latham, "The effect of mental practice and goal setting as a transfer of training intervention on supervisors' selfefficacy and communication skills: An exploratory study," Appl. Psychol., 2000, [Online]. Available: https://iaapjournals.onlinelibrary.wiley.com/doi/abs/10.1 111/1464-0597.00032.

[11] K. W. Cullen, T. O. M. Baranowski, and S. P. Smith, "Using goal setting as a strategy for dietary behavior change," J. Am. Diet. ..., 2001, [Online]. Available: https://www.sciencedirect.com/science/article /pii/S0002822301001407.

[12] F. C. Lunenburg, "Goal-setting theory of motivation,” Int. J. Manag. business, ..., 2011, [Online]. Available: https://www.goalhub.com/s/Lunenburg-FredC-Goal-Setting-Theoryof-MotivationIJMBA-V15-N1-2011.pdf.

[13] A. J. Moeller, J. M. Theiler, and C. Wu, "Goal Setting and Student Achievement: A 
Longitudinal Study," Mod. Lang. J., vol. 96, no. 2, pp. 153-169, 2012, doi: 10.1111/j.15404781.2011.01231.x.

[14] G. P. Latham, J. Brcic, and A. Steinhauer, "Toward an integration of goal setting theory and the automaticity model," Appl. Psychol., 2017, [Online]. Available: https://iaapjournals.onlinelibrary.wiley.com/doi/abs/10.1 111/apps.12087.

[15] R. Dotson, "Goal Setting to Increase Student Academic Performance," J. Sch. Adm. Res. Dev. Summer, vol. 1, no. 1, p. 44, 2016, [Online]. Available: http://www.education.com/reference/article/g oal-.

[16] A. J. Moeller, J. M. Theiler, and C. Wu, "Goal setting and student achievement: A longitudinal study," Mod. Lang. J., 2012, [Online]. Available: https://onlinelibrary.wiley.com/doi/abs/10.11 11/j.1540-4781.2011.01231.x.

[17] P. H. White, M. M. Kjelgaard, and S. G. Harkins, "Testing the contribution of selfevaluation to goal-setting effects.," $J$. Personal. ..., 1995, [Online]. Available: https://psycnet.apa.org/doiLanding?doi=10.1 037/0022-3514.69.1.69.

[18] L. Monzani, P. Ripoll, and J. M. Peiró, "Winning the hearts and minds of followers: The interactive effects of followers' emotional competencies and goal setting types on trust in leadership," Rev. Latinoam. Psicol., vol. 47, no. 1, pp. 1-15, 2015, doi: 10.1016/s01200534(15)30001-7.

[19] W. L. Cron, J. W. Slocum, Jr, D. VandeWalle, and ..., "The role of goal orientation on negative emotions and goal setting when initial performance falls short of one's performance goal," Hum. Perform., 2005, [Online]. Available: https://www.tandfonline.com/doi/abs/10.120 7/s15327043hup1801_3.

[20] E. A. Locke and G. P. Latham, "New directions in goal-setting theory," Curr. Dir. Psychol. Sci., vol. 15, no. 5, pp. 265-268, 2006, doi: 10.1111/j.14678721.2006.00449.x.

[21] J. Creswell, "Qualitative, quantitative, and mixed methods approaches," Res. Des., pp. 126, 2013, doi: 10.2307/3152153.

[22] M. Saleh, "Merdeka Belajar di Tengah Pandemi Covid-19,", Pros. Semin. Nas.
Hardiknas, vol. 1, pp. 51-56, 2020, [Online]. Available:

http://proceedings.ideaspublishing.co.id/inde x.php/hardiknas/article/view/8.

[23] N. Siregar, R. Sahirah, and A. A. Harahap, "Konsep Kampus Merdeka Belajar Di Era," FitrahJournal Islam. Educ., vol. 1, no. 1, pp. 141-157, 2020.

[24] E. Aktan and B. Sari, "An inquiry on application process of EU Erasmus programme \& students' views regarding Erasmus programme of student exchange," Exedra, no. Special Issue, pp. 239-268, 2010.

[25] R. Flatley, M. A. Weber, S. Czerny, and S. Pham, "Librarians and mandatory academic advising at a mid-sized public university: A case study," J. Acad. Librariansh., vol. 39, no. 6, pp. 582-587, 2013, doi: 10.1016/j.acalib.2013.01.006.

[26] D. J. Menke, M. Duslak, and C. M. McGill, "Administrator Perceptions of Academic Advisor Tasks," NACADA J., vol. 40, no. 2, pp. 85-96, 2020.

[27] A. Grashinta, A. P. Istiqomah, and E. P. Wiroko, "Pengaruh Future Time Perspective Terhadap Kematangan Karir Pada Mahasiswa," J. Psikol. Pendidik. dan Konseling J. Kaji. Psikol. Pendidik. dan Bimbing. Konseling, vol. 4, no. 1, p. 25, 2018, doi: 10.26858/jpkk.v4i1.4981.

[28] K. W. Mossholder, "Effects of externally mediated goal setting on intrinsic motivation: A laboratory experiment.," J. Appl. Psychol., 1980, [Online]. Available: https://psycnet.apa.org/record/1981-11912001. 